\title{
Gaya Komunikasi Guru dan Motivasi Belajar Siswa pada Pembelajaran Daring di Masa Pandemi COVID-19
}

\author{
https://doi.org/10.25008/caraka.v2i1.56 \\ Alifia Nurul Fadhilah, Fajar Iqbal \\ Universitas Islam Negeri Sunan Kalijaga - Yogyakarta
}

\begin{abstract}
ABSTRAK
Penelitian ini mengkaji besaran pengaruh gaya komunikasi guru terhadap motivasi belajar siswa pada pembelajaran daring masa pandemi COVID-19. Pandemi COVID-19 sejak tahun 2020 berdampak pada Pendidikan di Indonesia khususnya dalam kegiatan belajar mengajar yang dilakukan secara online. Di masa pandemi COVID-19 merupakan sebuah tantangan bagi para guru untuk menumbuhkan motivasi belajar siswa yang rendah pada pembelajaran daring. Guru sebagai tenaga pendidik dan pengajar menjadi seseorang yang memegang peranan penting dalam mewujudkan generasi penerus bangsa yang cerdas dan berprestasi. Gaya komunikasi guru diduga kuat sangat mempengaruhi motivasi belajar siswa. Pada penelitian ini motivasi belajar siswa diukur menggunakan referensi teori kemungkinan elaborasi yang dikembangkan Richard Petty dan John Cacioppo. Penelitian ini merupakan penelitian kuantitatif dengan teknik pengumpulan data menggunakan kuisioner. Analisis data menggunakan rumus analisis regresi linier sederhana yang digunakan untuk mengetahui besar pengaruh gaya komunikasi guru terhadap motivasi belajar siswa, menggunakan IBM Statictic versi 25 . Penelitian ini dilakukan terhadap 70 siswa kelas delapan di MTs Negeri 4 Bantul yang dilakukan secara online. Hasil penelitian ini menunjukkan, terdapat pengaruh yang signifikan antara gaya komunikasi guru terhadap motivasi belajar siswa pada pembelajaran daring masa pandemi COVID-19. Pertambahan motivasi belajar siswa sangat ditentukan oleh gaya komunikasi guru saat melaksanakan kegiatan belajar mengajar secara daring pada masa pandemi COVID-19.
\end{abstract}

Kata Kunci: Kemungkinan elaborasi, gaya komunikasi, motivasi belajar, pembelajaran daring, COVID-19.

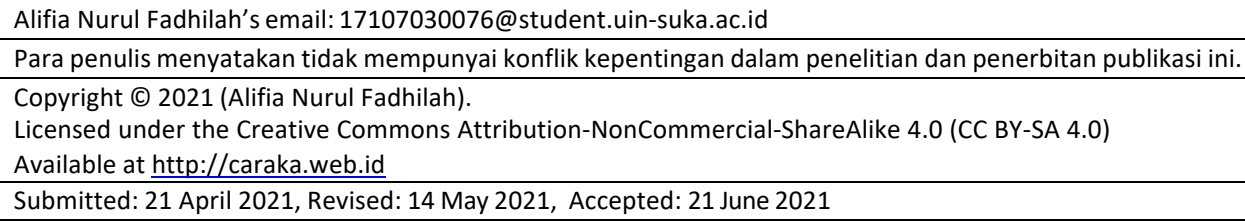




\section{PENDAHULUAN}

Tahun 2020 menjadi awal terjadinya wabah virus corona di Indonesia yang berasal dari Wuhan, Tiongkok. Virus corona merupakan penyebab penyakit Corona Virus Diseases 2019 (COVID-19) yang tidak dapat diremehkan, dan dapat mematikan. Sejak 11 Maret 2020, WHO (World Health Organization) menetapkan COVID-19 sebagai pandemi. Penyakit COVID-19 meresahkan dunia, membuat umat manusia harus waspada dan berhati-hati dengan menjaga protokol kesehatan dalam kehidupan sehari-hari.

Salah satu kebijakan yang diterapkan Indonesia untuk mencegah penularan COVID-19 adalah membuat kebijakan bagi siswa dan mahasiswa untuk belajar dari rumah melalui sistem pembelajaran daring (dalam jaringan) atau online (Detikcom, 2020). Pembelajaran online ini pada awalnya telah di kembangkan sebelum adanya COVID-19. Pembelajaran daring memanfaatkan teknologi internet dan dilakukan dengan menggunakan media cetak (modul) ataupun noncetak seperti audio, video, internet berupa media sosial, dan siaran radio dan televisi.

Pada masa pandemi COVID-19 pembelajaran daring diterapkan sehingga kegiatan belajar mengajar tetap terlaksana tanpa tatap muka secara langsung dengan pelajar/mahasiswa. Pelaksanaan pembelajaran daring ini dilaksanakan agar para pelajar tetap dapat melakukan kegiatan belajar sebagaimana mestinya tanpa ada hambatan, karena pembelajaran harus terus berjalan demi terwujudnya generasi penerus bangsa Indonesia yang berwawasan luas dan cerdas.

Selama pembelajaran daring, banyak siswa yang merasa bosan karena rutinitas belajar dijalankan di rumah tanpa bertemu dengan teman dan guru. Hal ini menjadi permasalahan batin tersendiri. Tetapi banyak siswa yang masih memiliki motivasi belajar karena mereka memegang teguh perintah Allah dalam Qur'an Surat. Al-Alaq 96:1-5 yang berbunyi :

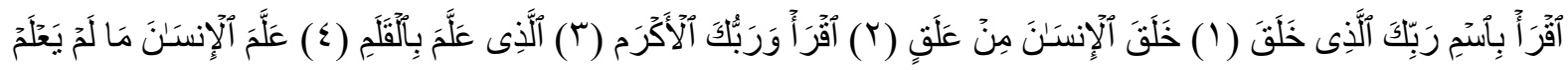

Artinya: "Bacalah dengan (menyebut) nama Tuhanmu Yang menciptakan, Dia telah menciptakan manusia dari segumpal darah. Bacalah, dan Tuhanmulah Yang Maha Pemurah. Yang mengajar (manusia) dengan perantaraan kalam. Dia mengajarkan kepada manusia apa yang tidak diketahuinya"

Dari Qur'an Surat Al-Alaq ayat 1-5 tersebut Allah memerintahkan hambanya untuk belajar tentang apa saja yang telah Allah ciptakan seperti ilmu yang bermanfaat bagi manusia. Dengan adanya ayat ini setiap manusia memiliki tujuan belajar selain menggapai cita-cita juga ibadah kepada Allah SWT. Begitulah para pelajar di Indonesia dapat bertahan untuk belajar pada masa pandemi COVID-19.

Sampai saat ini para siswa sudah setahun lebih melaksanakan sistem pembelajaran daring. Menurut hasil penelitian (Hidayat \& Noeraida, 2020), sistem pembelajaran daring memiliki kekuatan atau kelebihan yaitu akses pengayaan materi melalui internet, kegiatan belajar yang fleksibel, dan tidak terbatas ruang dan waktu. Akan tetapi ada kelemahan dalam pembelajaran daring yaitu jaringan internet yang terkadang tidak stabil, keterbatasan komunikasi dua arah, kurang dinamis sehingga motivasi siswa kurang terbangun, siswa juga kurang menangkap pesan nonverbal yang dilakukan oleh guru, dan kondisi siswa yang membuat dia pasif sehingga menimbulkan banyak keluhan yang muncul dari siswa seperti sistem pembelajaran daring lebih rumit dari tatap muka biasanya, banyaknya tugas dari guru dan dikejar-kejar deadline, hingga terbatasnya waktu bagi siswa untuk bertanya pada guru.

Sebenarnya banyak hal yang perlu dievaluasi selama proses pembelajaran daring dilaksanakan, 
misalnya, gaya komunikasi guru selama menyampaikan sebuah materi. Terlepas dari tugas yang diberikan, baiknya guru memberikan penjelasan sebelumnya sehingga siswa lebih terarah dan memahami materi pembelajaran. Termasuk, bagaimana gaya komunikasi penyampaian guru dari mulai bahasa, kata-kata, dan berbagai bentuk gaya komunikasi yang diterapkan dapat diterima oleh siswa selama proses belajar.

Ciputra (2016) menyatakan, guru memiliki acuan silabus dan kurikulum sesuai dengan Standar Kompetensi Nasional sehingga tidak ada perbedaan pengetahuan setiap siswa di sekolah yang satu dan sekolah lainnya. Pada rencana pelaksanaan pembelajaran (RPP), guru akan memasukan elaborasi, yaitu penggarapan sesuatu dengan tekun dan cermat terhadap suatu hal. Elaborasi ini merupakan sebuah proses seseorang menganalisis dan memperdalam kemampuannya secara terus menerus melakukan sebuah pembelajaran. Pada pembelajaran yang disampaikan, guru berkewajiban untuk mengarahkan siswa, tetapi tetap menyerahkan pemikiran secara bebas kepada siswa.

Guru merupakan seorang pengajar dan pendidik yang memberikan materi berupa pelajaran sesuai bidangnya dan juga mendidik siswa sekolah agar lebih baik dalam bersikap dan berbudi. Sebagai seorang guru yang setiap hari juga melakukan sistem pembelajaran daring pastilah dapat memahami dan menyikapi bagaimana cara mengajar yang baik dan dapat diterapkan selama masa pandemi COVID-19. Sebagai pengendali kelas sistem pembelajaran daring atau online, guru juga memiliki andil untuk meningkatkan motivasi belajar siswa. Proses komunikasi dan gaya komunikasi yang dilakukan oleh guru pastilah memiliki ciri dan gaya masing-masing, akan tetapi selama sistem pembelajaran daring, siswa tidak dapat melihat secara guru secara verbal. Contohnya, komunikasi dilakukan melalui chat WhatsApp sehingga siswa tidak mengetahui rupa dan gerakan guru tersebut.

Menurut Nasution (2020), saat pembelajaran daring siswa berkemungkinan menjadi kurang aktif dalam menyampaikan pemikirannya dan membuat belajar menjadi cepat bosan karena pasif, karena para siswa belajar tanpa harus datang ke sekolah sehingga mempengaruhi motivasi belajar mereka.

Motivasi belajar merupakan pendorong yang membuat seseorang tertarik dan senang belajar sehingga terus belajar. Motivasi belajar sangat diperlukan sebagai penunjang semangat belajar untuk menggapai cita-cita yang dimiliki oleh pelajar. Dalam belajar tidak hanya materi yang didapat tetapi juga bagaimana siswa dapat memahami dan menerapkannya dengan semangat dan bahagia. Proses belajar inilah yang nantinya akan membekas dan mengasah keterampilan berfikir siswa dalam pembentukan karakter. Kehilangan motivasi belajar akan membuat seorang siswa menjadi cepat bosan belajar dan pada akhirnya berujung pada kemalasan.

Motivasi belajar yang rendah juga menyebabkan rendahnya keberhasilan dalam pembelajaran sehingga menurunkan nilai prestasi belajar. Kehilangan motivasi belajar bisa disebabkan karena kurangnya pemahaman terhadap materi ataupun adanya beban yang menyebabkan terhambatnya suatu pekerjaan sehingga mempengaruhi berbagai hal dari dalam diri manusia. Tidak hanya dalam tindakan tetapi pikiran dan perasaan juga terganggu. Minimnya fasilitas belajar daring juga terjadi karena tidak semua orang tua dapat menyediakan fasilitas yang sama seperti di sekolah.

Menurut Muhibbin Syah (2008), terdapat beberapa faktor yang mempengaruhi motivasi belajar pada siswa. Faktor-faktor tersebut adalah faktor eksternal, faktor internal, dan faktor pendekatan belajar. Dari tiga faktor tersebut, salah satu faktor yang dekat dengan penelitian ini adalah faktor eksternal. Faktor eksternal ini terkait dengan lingkungan sosial seperti guru, dosen atau pengajar, dan teman-teman sekelasnya. Salah satu unsur yang dapat mempengaruhi motivasi dan semangat belajar seorang siswa adalah guru. Bila guru menunjukkan perilaku simpatik, 
mendidik, dan memberikan contoh teladan baik pada siswanya maka akan meningkatkan motivasi belajar siswa tersebut.

Selama Pandemi COVID-19, MTs Negeri 4 Bantul juga memberlakukan pembelajaran daring, namaun dalam kegiatan tersebut selalu ada siswa yang tidak mengumpulkan tugas sehingga harus berurusan dengan guru mata pelajaran, wali kelas, dan guru bimbingan konseling. Alasan siswa tidak mengumpulkan tugas bermacam-macam, seperti tidak tahu jika ada tugas, tidak tahu jika ada kelas, dan tidak memiliki paket data kuota internet padahal sekolah sudah mengusahakan setiap siswa mendapat paket data internet. Dari alasan-alasan siswa tersebut, peneliti tergugah untuk meneliti motivasi belajar siswa kelas 8 di MTs N 4 Bantul.

Gaya komunikasi guru terbagi menjadi tiga macam gaya yaitu passive style, assertive style, dan aggressive style. Tiga macam gaya yang berbeda tersebut akan mempengaruhi motivasi belajar siswa yang berbeda pula. Motivasi belajar siswa diukur berdasarkan lima indikator yaitu adanya hasrat dan keinginan untuk berhasil dalam belajar, adanya keinginan, semangat dan kebutuhan dalam belajar, memiliki harapan dan cita-cita masa depan, adanya pemberian penghargaan dalam proses belajar, adanya lingkungan yang kondusif untuk belajar dengan baik.

\section{KERANGKA TEORI}

Menurut Griffin (2012), ada dua jalan dalam mengevaluasi atau mengolah suatu informasi yaitu: (1) Central (terpusat). Pada rute terpusat ini seseorang yang menerima pesan akan berfikir secara panjang dengan pemikiran yang kritis. Syaratnya adalah argumen dari pesan yang terima harus relevan, dapat diterima oleh akal dan sumber informasi yang kuat. Jalan ini digunakan ketika seseorang memproses informasi yang diterima dengan menggunakan cara seperti menyelidiki informasi tersebut dengan mempertimbangkan keuntungan baik dan buruknya, dan dampak apabila mengabaikannya. Pada rute ini keputusan yang diambil akan dilakukan dengan penuh pertimbangdan dan secara sadar yang pada akhirnya dapat mengubah individu dalam bersikap; (2) Periferal (tepi). Pada rute tepi ini seseorang atau individu tidak berfikir secara kritis seperti pada rute terpusat. Rute tepi ini adalah kebalikan dari rute terpusat. Rute ini merujuk pada keputusan menerima atau menolak sebuah pesan tanpa memperhatikan atau mempertimbangkan sebuah pesan tersebut akan berdampak apa dalam dirinya. Apabila seseorang terdampak sebuah pesan dan menggunakan rute ini maka perubahan sikap tersebut akan berlangsung secara temporer, karena rute tepi ini dipengaruhi oleh lingkungan sekitar.

Menurut Littlejohn \& Foss (2011), kedua rute merujuk pada kesamaan pemahaman antara pengirim dan penerima pesan. Bagaimana pemikiran yang dilakukan atau diambil oleh seseorang itu ditentukan oleh tingkat pengembengan seseorang dan dalam mengambilnya juga dipengaruhi faktor motivasional dan faktor kemampuan.

Menurut Griffin (2012), seseorang dalam memproses sebuah pesan dipengaruhi sebuah motivasi (dorongan) dan kemampuan dari individu tersebut. Petty dan Cacioppo mengatakan, setiap orang pasti berusaha menyesuaikan diri terhadap kondisi yang dihadapi tetapi terkadang individu tidak memiliki ketertarikan atau minat terhadap informasi tertentu sehingga dorongan untuk mengelaborasi pesan menurun. Menurut Petty dan Cacioppo, dalam rute terpusat, seseorang yang memiliki kedekatan emosional secara pribadi dalam mengolah suatu pesan, mereka akan lebih terpengaruh oleh pesan tersebut daripada karakteristik pihak yang menyampaikan, tetapi apabila topik yang di sampaikan tidak menarik, maka pesan akan diterima dalam rute tepi sehingga penentuan sikap individu akan dipengaruhi oleh kredibilitas pesan.

Sedangkan dalam segi kemampuan, individu akan mengidentifikasi suatu pesan berdasarkan keadaan dirinya yang mampu atau tidak dalam melakukan sesuatu sesuai pesan tersebut. Ketika 
dia merasa mampu maka pesan akan dielaborasi melalui rute terpusat dan apabila dia merasa tidak mampu maka pesan akan teralih pada rute tepi.

Dalam penelitian ini, teori kemungkinan elaborasi digunakan untuk mengukur seberapa termotivasi siswa. Saat siswa memiliki motivasi tinggi maka dia berada di rute terpusat atau central sehingga fikirannya bekerja secara fokus dan kritis dalam menanamkan tujuan belajar. Sedangkan ketika siswa yang memiliki motivasi rendah, maka ia berada di rute periferal sehingga fikirannya kurang bekerja kritis atau tidak tertarik dan tidak sesuai dengan minat atau tujuan yang dia miliki. Dia masih membutuhkan dorongan yang lebih untuk membuatnya semangat dalam belajar.

Sementara itu Heffner membuat klasifikasi gaya komunikasi berdasar karya Mc Callister (Liliweri, 2015), yaitu: (1) Passive Style. Gaya komunikasi pasif ini ditandai dengan guru menyerahkan keputusan kepada siswa dan cenderung menunda proses pengambilan keputusan. Gaya komunikasi tersebut, guru memilih diam atau mengiyakan, sulit menolak demi menghindari konflik; (2) Assertive Style. Gaya komunikasi assertive merupakan sebuah gaya komunikasi yang bersifat tegas, percaya diri dengan pendekatan yang jujur dan terbuka dalam menyampaikan sebuah pendapat, kebutuhan, keinginan dengan tidak melanggar hak, agresi, dan menyakiti orang lain yaitu dengan tujuan mengejar keinginannya tanpa melanggar kebutuhan orang lain; (3) Aggressive Style. Gaya komunikasi aggressive merupakan gaya komunikasi yang mengekspresikan diri mereka dengan merasa berkuasa atau superior, mau menang dan benar sendiri, juga mengabaikan perasaan dan hak-hak orang lain. Sebuah sikap dengan mempertahankan suatu pendapat tanpa mempedulikan dan mempertimbangkan orang lain. Seperti pada saat melakukan pembelajaran tiba-tiba meminta perhatian dengan cara menunjuk dan menggebrak meja. Seorang guru dengan gaya ini selalu menganggap dirinya benar dan tidak mau menerima pernyataan dari muridnya walaupun pendapat murid lebih tepat dan baik.

Motivasi Belajar merupakan energi yang mendorong suatu keinginan yang mengguggah seseorang untuk mempelajari atau mendapatkan sebuah tantangan baru bagi dirinya. Menurut Rohmah (2015), motivasi belajar dapat dianalogikan seperti bahan bakar yang dapat menggerakan mesin. Motivasi belajar inilah yang akan mendorong siswa menjadi lebih giat dan aktif untuk meningkatkan prestasi belajar.

Ada lima indikator atau petunjuk yang dijadikan acuan untuk mengukur motivasi belajar siswa yaitu: (1) Adanya hasrat dan keinginan untuk berhasil dalam belajar. Suatu hasrat dan keinginan untuk belajar ini merupakan sebuah motif atau tujuan seseorang untuk berhasil. Salah satu contoh yaitu dalam melakukan sesuatu berupa menyelesaikan sebuah tugas dan tidak menunda-nunda pekerjaan karena dalam dirinya memiliki tujuan untuk berprestasi yang tinggi; (2) Adanya keinginan, semangat dan kebutuhan dalam belajar. Tidak hanya pada dirinya tetapi seseorang terkadang merasa termotivasi karena adanya dorongan dari luar yang menimbulkan semangat, keinginan, dan kebutuhan untuk berhasil atau berprestasi. Salah satu contoh adalah takut akan kegagalan, seseorang merasa malu apabila dia tidak dapat menyelesaikan tugas, mungkin bisa di olok-olok oleh temannya dan juga mendapat amarah dari orang tua dan guru. Sehingga keinginan berhasil dalam belajar tersebut muncul dari rangsangan luar dirinya; (3) Memiliki harapan dan citacita masa depan. Seseorang akan lebih termotivasi apabila memiliki harapan dan cita-cita yang terus menerus ia pikirkan dan inginkan. Dengan memiliki harapan dan cita-cita dia akan mewujudkan dengan berbagai usaha sehingga terdorong siswa untuk belajar dan berprestasi meraih cita-cita yang dia inginkan; (4) Adanya pemberian penghargaan dalam proses belajar. Pemberian penghargaan berupa pujian dan perilaku yang baik dalam menyikapi seseorang dapat meningkatkan motif belajar. Sehingga secara umum siswa akan merasa diakui dan di kagumi oleh 
guru, hal tersebut akan memacu siswa untuk lebih termotivasi dalam belajar dan berprestasi; (5) Adanya lingkungan yang kondusif untuk belajar dengan baik. Lingkungan yang kondusif akan mempengaruhi mood atau perasaan siswa sehingga dapat menerima materi dengan baik dan menyenangkan. Lingkungan tersebut berupa suasana yang mendukung untuk dia belajar, yaitu apabila dia merasa kesulitan dalam belajar maka dia dapat memperoleh bantuan yang tepat untuk mengatasi kesulitan tersebut.

\section{Pembelajaran Dalam Jaringan (Daring)}

Direktorat Pembelajaran dan Kemahasiswaan dan Direktorat Jenderal Pendidikan Tinggi memulai pengembangan program Pembelajaran Daring Indonesia Terbuka dan Terpadu (PDITT) tahun 2014, dan diresmikan oleh Wakil Presiden Boediono pada 15 Oktober 2014. Setelah dua tahun berjalan, pada 18 September 2016, PDITT berganti nama menjadi Sistem Pembelajaran Daring (SPADA). Tujuan dari program ini pada awalnya dikhususkan bagi mahasiswa sebagai pemerataan akses terhadap suatu lingkup mata kuliah dengan sistem mengajar jarak jauh.

Sistem Pembelajaran daring ini tujuannya adalah pemerataan materi dari kampus unggul dengan kampus yang biasa saja agar mahasiswa dari kampus yang biasa saja tersebut dapat mengikuti suatu mata kuliah yang bermutu dari perguruan tinggi yang lebih unggul.

Mustofa, Chodzirin, Sayekti, \& Fauzan (2019) mengatakan, model pembelajaran daring adalah suatu sistem yang menggunakan bantuan teknologi sehingga dapat melakukan pembelajaran jarak jauh dengan internet sehingga pengajar dan pelajar tidak perlu melakukan tatap muka langsung selama proses belajar. Semua materi dan tugas juga diberikan dan dikumpulkan secara online. Di dalam pembelajaran daring juga terdapat metode mengajar yang berbeda dengan kegiatan belajar mengajar pada umumnya.

Harnani (2020) mengatakan, pembelajaran daring merupakan suatu sistem pembelajaran antara guru dan siswa yang tidak bertemu secara langsung dan dilaksanakan secara online dengan menggunakan jaringan internet. Pada sistem pembelajaran daring di pandemi COVID-19, guru bertugas memberikan materi dan mengajar meskipun siswa berada di rumah. Sistem pembelajaran daring ini menuntut guru untuk mengeksplor cara mengajar yang inovatif dengan menggunakan media online. Pembelajaran daring ini juga memiliki hal positif karena seseorang dapat belajar dan berinteraksi dimana saja dan kapan saja menggunakan internet.

\section{METODOLOGI}

Penelitian ini menggunakan jenis penelitian pendekatan kuantitatif. Menurut Sugiyono (2013), metode penelitian kuantitatif adalah sebuah metode penelitian yang dilandasi dari pemikiran filsafat positivisme. Penelitian kuantitatif ini bertujuan untuk meneliti suatu populasi tertentu. Cara melakukan pengumpulan data pada jenis penelitian ini adalah menggunakan alat atau salah satu instrument penelitian, dan analisis data yang bersifat statistik untuk menguji hipotesis yang telah dirumuskan.

Peneliti menggunakan metode survei sebagai metode penelitian. Metode survei dilaksanakan dengan menggunakan pertanyaan atau pernyataan terstruktur dan sistematis (kuisioner) yang sama kepada banyak orang atau dalam suatu populasi dan seluruh jawaban yang diperoleh peneliti adalah data yang dikumpulkan, llau diolah dan dianalisis.

Penelitian dilakukan dengan 70 responden berdasarkan dua variabel bebas yaitu gaya komunikasi guru dan variabel terikat motivasi belajar siswa. Dengan item pernyataan variabel bebas sebanyak enam item dan item pernyataan variabel terikat sebanyak 16 item. Keseluruhan data yang di dapatkan dari 70 responden tersebut diolah menggunakan software IBM Statictic SPSS 
versi 25.

\section{HASIL PENELITIAN}

Uji Validitas. Peneliti menggunakan IBM SPSS Statistic versi 25 untuk menguji validitas setiap item pernyataan kuisioner. Tujuannya agar setiap item pernyataan valid sehingga ideal untuk mengukur apa yang dirasakan responden. Dalam menentukan valid atau tidaknya item pernyataan, peneliti menggunakan teknik perbandingan antara rtabel dengan rhitung. Peneliti mengambil 33 responden untuk uji validitas menggunakan tingkat signifikansi sebesar $5 \%$ sehingga nilai rtabel yang dijadikan pembanding adalah 0.3440 . Item pernyataan dinyatakan valid apabila rhitung lebih besar daripada rtabel.

Tabel 1. Hasil Uji Validitas Variabel X (Gaya Komunikasi Guru)

\begin{tabular}{|c|c|c|c|}
\hline No Item & rtabel & rhitung & Hasil Instrumen \\
\hline X1 & 0,3440 & 0,561 & Valid \\
\hline X2 & 0,3440 & 0,499 & Valid \\
\hline X3 & 0,3440 & 0,661 & Valid \\
\hline X5 & 0,3440 & 0,672 & Valid \\
\hline X6 & 0,3440 & 0,711 & Valid \\
\hline
\end{tabular}

Sumber: Olahan Data IBM SPSS Statistic versi 25

Tabel 2. Hasil Uji Validitas Variabel Y (Motivasi Belajar Siswa)

\begin{tabular}{|c|c|c|c|}
\hline No Item & rtabel & rhitung & Hasil Instrumen \\
\hline Y1 & 0,3440 & 0,584 & Valid \\
\hline Y2 & 0,3440 & 0,726 & Valid \\
\hline Y3 & 0,3440 & 0,789 & Valid \\
\hline Y4 & 0,3440 & 0,520 & Valid \\
\hline Y5 & 0,3440 & 0,584 & Valid \\
\hline Y6 & 0,3440 & 0,663 & Valid \\
\hline Y7 & 0,3440 & 0,576 & Valid \\
\hline Y8 & 0,3440 & 0,748 & Valid \\
\hline Y9 & 0,3440 & 0,764 & Valid \\
\hline Y10 & 0,3440 & 0,548 & Valid \\
\hline Y11 & 0,3440 & 0,548 & Valid \\
\hline Y12 & 0,3440 & 0,516 & Valid \\
\hline Y13 & 0,3440 & 0,642 & Valid \\
\hline Y14 & 0,3440 & 0,486 & Valid \\
\hline Y15 & 0,3440 & 0,659 & Valid \\
\hline Y16 & 0,3440 & 0,593 & Valid \\
\hline
\end{tabular}

Sumber: Olahan Data IBM SPSS Statistic versi 25

Berdasarkan hasil uji validitas variabel $X$ (gaya komunikasi guru) dan variabel $Y$ (motivasi belajar siswa), dapat disimpulkan item pernyataan variabel $X$ (gaya komunikasi guru) dan variabel Y (motivasi belajar siswa) dapat dinyatakan valid.

Uji Reliabilitas. Setelah melakukan uji validitas, dan item pernyataan dinyatakan valid maka dilakukan uji reliabilitas untuk melihat apakah kuisioner sudah reliabel. Item pernyataan dapat dikatakan reliabel apabila hasil dari Cronbach Alpha $>0,60$. Berikut adalah hasil uji reliabilitas dari 33 responden yang melakukan uji coba kuisioner: 


\section{Reliability Statistics}

\begin{tabular}{c|r}
$\begin{array}{c}\text { Cronbach's } \\
\text { Alpha }\end{array}$ & N of Items \\
\hline .683 & 6 \\
\hline
\end{tabular}

Gambar 1. Hasil Uji Reliabilitas Variabel X (Gaya Komunikasi Guru)

Sumber: Olahan Data IBM SPSS Statistic versi 25

\section{Reliability Statistics}

\begin{tabular}{r|r}
$\begin{array}{c}\text { Cronbach's } \\
\text { Alpha }\end{array}$ & N of Items \\
\hline .887 & 16 \\
\hline
\end{tabular}

Gambar 2. Hasil Uji Reliabilitas Variabel Y (Motivasi Belajar Siswa

Sumber: Olahan Data IBM SPSS Statistic versi 25

Berdasarkan hasil uji reliabilitas, variabel X memiliki Cronbach Alpha sebesar 0,683 dan variabel Y memiliki Cronbach Alpha sebesar 0,887. Maka dapat disimpulkan, variabel X (gaya komunikasi guru) dan variabel $Y$ (motivasi belajar siswa) memiliki nilai koefisien alpha yang lebih dari 0,60 sehingga kedua variabel tersebut dinyatakan reliabel.

Uji Normalitas. Peneliti melakukan uji normalitas untuk mengetahui variabel $\mathrm{X}$ (gaya komunikasi guru) dan variabel $Y$ (motivasi belajar siswa) dalam pendistribusiannya. Pengujian menggunakan uji One-Sample Kolmogrov-Smirnov Test, diukur berdasarkan tingkat signifikasi 0,05. Pendistribusian variabel dikatakan normal bila hasil uji normalitas lebih dari 0,05 . Berikut adalah hasil uji normalitas dari data 70 responden yang telah dikumpulkan:

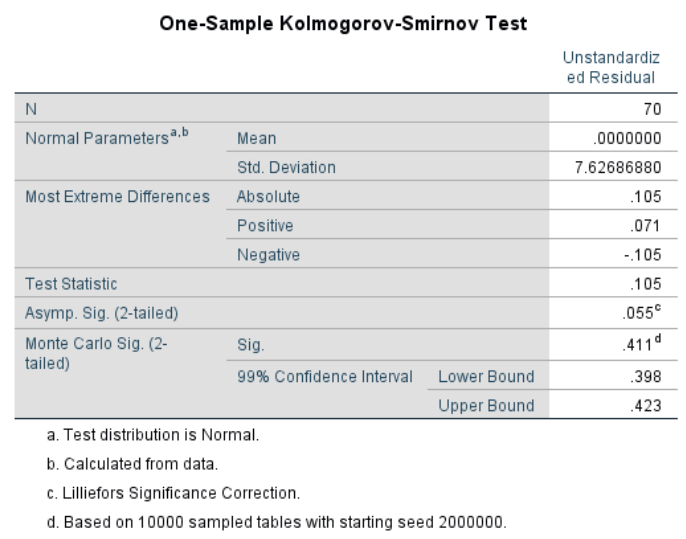

Gambar 3. Data Hasil Uji Normalitas One-Sample Kolmogrov-Smirnov Sumber: Olahan Data IBM SPSS Statistic versi 25

Berdasarkan hasil uji normalitas One-Sample Kolmogrov-Smirnov Test, nilai signifikansinya adalah 0,411, memiliki nilai signifikansi lebih dari 0,05. Dapat disimpulkan, item variabel $X$ (gaya komunikasi guru) dan variabel Y (motivasi belajar siswa) terdistribusi dengan normal.

Uji Linieritas, dilakukan untuk mengetahui apakah kedua variabel memiliki hubungan linier yang signifikan. Untuk mengetahui kedua variabel tersebut saling berhubungan secara linier, hasil dari uji linieritas nilai signifikansinya harus lebih dari 0,05. Jika nilainya lebih dari nilai signifikansi maka variabel dapat dikatakan terdapat hubungan linear satu sama lain. 
Berikut adalah hasil uji linieritas dari data 70 responden yang telah dikumpulkan oleh peneliti:

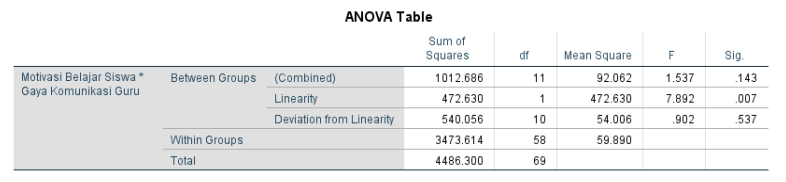

Gambar 4. Data Hasil Uji Linieritas Variabel X dan Variabel Y Sumber: Olahan Data IBM SPSS Statistic versi 25

Berdasarkan hasil uji linieritas variabel $X$ (gaya komunikasi guru) dan variabel $Y$ (motivasi belajar siswa) diketahui nilai signifikansi hubungan kedua variabel adalah 0,537 pada bagian Deviation from Linearity yang lebih dari standar nilai signifikansinya adalah 0,05 . Jadi, dari hasil uji linieritas di IBM SPSS Statistic versi 25, variabel gaya komunikasi guru terdapat hubungan yang linier terhadap motivasi belajar siswa.

Regresi Linier Sederhana. Pada penelitian ini, digunakan analisis regresi linier sederhana dalam uji analisis data dari 70 responden. Analisis regresi linier sederhana ini berfungsi untuk mengetahui seberapa besar hubungan antara variabel $X$ (gaya komunikasi guru) dan variabel Y (motivasi belajar siswa). Peneliti melakukan olah data menggunakan IBM SPSS Statistic versi 25 . Berikut adalah hasil olah data analisis regresi linier sederhana:

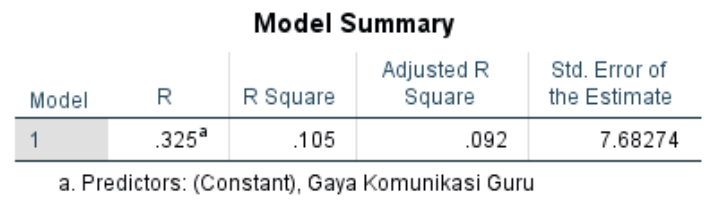

Gambar 5. Data Hasil Koefiesien

Sumber: Olahan Data IBM SPSS Statistic versi 25

Berdasarkan Gambar 5, hasil koefisien uji analisis data regresi linier sederhana nilai korelasi R antara variabel gaya komunikasi guru terhadap variabel motivasi belajar siswa sebesar 0,325 yang berarti tingkat hubungan antara variabel gaya komunikasi guru terhadap variabel motivasi belajar siswa dapat dikatakan rendah berdasarkan tabel interpretasi koefisien korelasi sebagai berikut:

Tabel 3. Tabel Interpretasi Koefisien Korelasi

\begin{tabular}{|c|l|}
\hline$R$ & \multicolumn{1}{|c|}{ Keterangan Tingkat Hubungan } \\
\hline $0,000-0,199$ & Sangat Rendah \\
\hline $0,200-0,399$ & Rendah \\
\hline $0,400-0,599$ & Cukup \\
\hline $0,600-0,799$ & Kuat \\
\hline $0,800-1$ & Sangat Kuat \\
\hline
\end{tabular}

Selain itu, berdasarkan Gambar 5 diperoleh persentase 0,105 (10,5\%) kontribusi variabel independent atau bebas terhadap variabel dependent atau terikat, berdasarkan data $\mathrm{R}$ Square atau Koefisien Determinasi yang tertera pada hasil olahan data IBM SPSS Statistic versi 25. Jadi, variabel gaya komunikasi guru memiliki pengaruh sebesar 10,5\% terhadap variabel motivasi belajar siswa, sedangkan $89,5 \%$ disebabkan oleh faktor lain. 


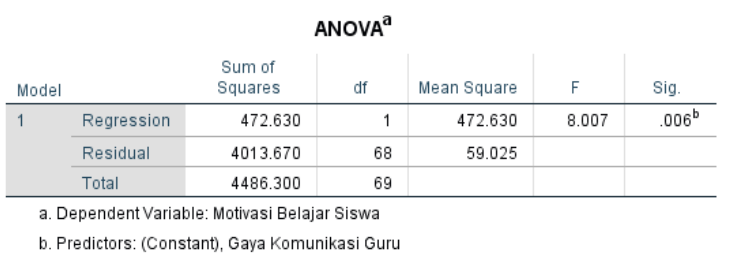

Gambar 6. Data Hasil Uji Signifikan

Sumber: Olahan Data IBM SPSS Statistic versi 25

Berdasarkan hasil uji signifikansi yang bertujuan untuk menguji apakah variabel independent terhadap variabel dependent memiliki nilai yang signifikan dalam mempengaruhinya dan berdasarkan Gambar 6 didapatkan nilai signifikansi sebesar 0,006 dengan nilai alpha 0,05. Kemudian hasil 0,006 memiliki nilai lebih kecil dari 0,05 sehingga dapat dikatakan normal. Kesimpulan dari olahan data IBM SPSS Statistic versi 25 adalah terdapat pengaruh yang signifikan antara gaya komunikasi guru terhadap motivasi belajar siswa pada pembelajara daring masa pandemi COVID-19.

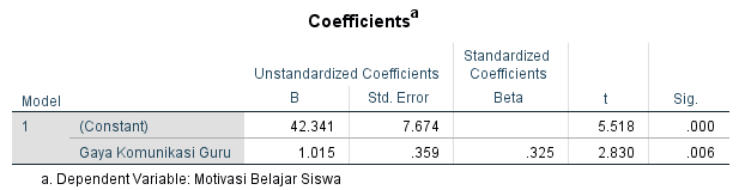

Gambar 7. Data Hasil Koefisien Regresi Sederhana Sumber: Olahan Data IBM SPSS Statistic versi 25

Berdasarkan rumus model persamaan regresi linear sederhana $(\mathrm{Y}=\mathrm{a}+\mathrm{bX})$, dari Gambar 7 didapat hasil koefisien variabel $X$ sebesar 1,015 sedangkan nilai konstanta sebesar 42,341 , sehingga model persamaan regresi linear yang diperoleh adalah $Y^{\prime}=42,341+1,015 X$.

Persamaan dari rumus tersebut dapat diartikan nilai konstanta sebesar 42,341, artinya nilai konsisten variabel motivasi belajar 42,341. Sedangkan koefisien regresi variabel $X$ sebesar 1,015 menyatakan bahwa setiap penambahan $1 \%$ gaya komunikasi guru maka nilai motivasi belajar siswa bertambah sebesar 1,015. Koefisien regresi tersebut juga bernilai positif sehingga arah pengaruh variabel gaya komunikasi guru terhadap motivasi belajar siswa pada pembelajaran darin masa pandemi COVID-19 adalah positif.

Uji Hipotesis. Untuk mengetahui koefisien regresi signifikan ata tidak signifikan maka dilakukan uji hipotesis. Dalam penelitian ini hipotesis dirumuskan sebagai berikut:

$\mathrm{HO}_{1}$ : Tidak terdapat pengaruh yang signifikan antara gaya komunikasi guru terhadap motivasi belajar siswa selama pandemi COVID-19;

$\mathrm{Ha}_{1}$ : Terdapat pengaruh yang signifikan antara Gaya komunikasi guru terhadap motivasi belajar siswa selama pandemi COVID-19;

$\mathrm{HO}_{2}$ : Gaya komunikasi guru terhadap motivasi belajar siswa selama pandemi COVID-19 memiliki pengaruh yang kecil;

$\mathrm{Ha}_{2}$ : Gaya komunikasi guru terhadap motivasi belajar siswa selama pandemi COVID-19 memiliki pengaruh yang besar. 
Berdasarkan hasil perumusan hipotesis tersebut, untuk mengetahui koefisien regresi signifikan atau tidak, peneliti melakukan uji hipotesis pertama dengan membandingkan nilai signifikansi dengan probabilitas 0,05. Jika nilai signifikansi dari hasil olah data lebih kecil dari 0,05 maka dapat disimpulkan terdapat pengaruh yang signifikan antara variabel $X$ (gaya komunikasi guru) terhadap variabel $Y$ (motivasi belajar siswa) dan jika lebih besar dari 0,05 maka tidak terdapat pengaruh yang signifikan.

Setelah uji hipotesis pertama ditentukan dengan membandingkan nilai signifikansi selanjutnya adalah uji hipotesis dua yaitu melihat nilai $\mathrm{R}$ dan $\mathrm{R}$ square untuk menentukan tingkat pengaruh yang rendah atau tinggi berdasarkan angka yang diperoleh desimal dan persentase yang di dapat dari Olahan Data IBM SPSS Statistic versi 25.

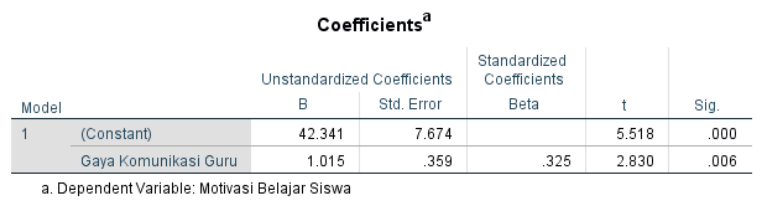

Gambar 8. Data Hasil Uji Hipotesis 1

Sumber: Olahan Data IBM SPSS Statistic versi 25

Berdasarkan Gambar 8, hasil uji hipotesis dari olahan data IBM SPSS Statistic versi 25 dapat diketahui bahwa nilai signifikansi sebesar 0,006 yang berarti lebih kecil dari 0,05, sehingga dapat dikatakan bahwa $\mathrm{HO}_{1}$ ditolak dan $\mathrm{Ha}_{1}$ diterima. Jadi berdasarkan data hasil olahan uji hipotesis tersebut dapat dikatakan bahwa terdapat pengaruh yang signifikan dari gaya komunikasi guru terhadap motivasi belajar siswa pada pembelajaran dari masa pandemi COVID-19.

\begin{tabular}{l|l|c|c|c}
\multicolumn{7}{c}{ Model Summary } \\
Model & $R$ & R Square & $\begin{array}{c}\text { Adjusted R } \\
\text { Square }\end{array}$ & $\begin{array}{c}\text { Std. Error of } \\
\text { the Estimate }\end{array}$ \\
\hline 1 & $.325^{\text {a }}$ & .105 & .092 & 7.68274 \\
\hline \multicolumn{3}{l}{ a. Predictors: (Constant), Gaya Komunikasi Guru }
\end{tabular}

Gambar 9. Data Hasil Uji Hipotesis 2

Sumber: Olahan Data IBM SPSS Statistic versi 25

Selanjutnya uji hipotesis kedua yaitu hasil yang didapat berdasarkan Olahan Data IBM SPSS Statistic versi 25 pada Gambar 9 menunjukkan hasil 0,325 yang menurut tabel 31 yaitu tabel interpretasi koefisien korelasi yang menunjukkan tingkat hubungan yang diperoleh adalah rendah sehingga uji hipotesis kedua ini dapat dikatakan $\mathrm{HO}_{2}$ diterima dan $\mathrm{Ha}_{2}$ di tolak. Selain itu berdasarkan nilai persentase yang diperoleh adalah10,5\%, pengaruh gaya komunikasi guru terhadap motivasi belajar siswa di kelas 8 MTs Negeri 4 Bantul pada pembelajaran daring masa pandemi COVID-19.

Analisis Data. Selama pandemi COVID-19 siswa melakukan pembelajaran daring dari rumah sehingga komunikasi dengan guru pun tidak sedekat saat berada di sekolah. Pembelajaran daring merupakan solusi perkembangan teknologi yang bermanfaat bagi pendidikan yang harus terus melaju di tengah pandemi COVID-19. Dengan pembelajaran daring pemberian pendidikan dan materi pelajaran terus berjalan untuk melawan kemalasan dan kebodohan warga negaranya.

Pada penelitian kali ini, peneliti telah melakukan penelitian tentang bagaimana gaya komunikasi guru dapat berpengaruh terhadap motivasi belajar siswa yang menlaksanakan pembelajaran daring masa pandemi COVID-19 ini. 
Sebelum penyebaran kuisoner penelitian, telah dilakukan uji instrument kepada 33 responden yang memiliki karakteristik yang sama untuk menentukan validitas dan reliabilitas kuisioner. Dari uji validitas dan uji reliabilitas yang didapat semua item pernyataan dinyatakan valid dan semua item pernyataan juga dinyatakan reliabel. Hasil tersebut dapat diketahui dengan membandingkan standar validitas dan standar reliabilitas sehingga seluruh item pernyataan tersebut dapat disebar kepada responden untuk diisi kemudian diolah.

Setelah data penelitian terkumpul, dilakukan uji asumsi berupa uji normalitas dan uji linieritas. Uji normalitas dengan rumus One-Sample Kolmogrov-Smirnov Test sebesar 0,411 sehingga data penelitian dapat dinyatakan berdistribusi dengan normal. Sedangkan pada uji linieritas didapatkan hasil dari Deviation from Linearity dengan signifikasi sebesar 0,537 sehingga dari hasil tersebut dapat dinyatakan terdapat hubungan linier antara gaya komunikasi guru terhadap motivasi belajar siswa pada pembelajaran dari masa pandemi COVID-19.

Peneliti selanjutnya melakukan uji analisis data menggunakan analisis regresi linier sederhana. Hasil ini berfungsi untuk mengetahui hubungan antara variabel gaya komunikasi guru dengan motivasi belajar siswa pada pembelajaran daring masa pandemi COVID-19. Berdasarkan gambar 5 (Data Hasil Koefisien) menyatakan nilai korelasi R antara variabel bebas (gaya komunikasi guru) terhadap variabel terikat (motivasi belajar siswa) sebesar 0,325 yang memiliki tingkat hubungan rendah. Walaupun tingkat hubungannya rendah pada pembelajaran dari masa pandemi COVID-19 ini, dalam uji signifikan pada Gambar 6 (Data Hasil Uji Signifikan) tetap terdapat pengaruh yang signifikan diantara kedua variabel tersebut.

Pada Gambar 5 (Data Hasil Koefisien) juga menyatakan pengaruh signifikan tersebut dari koefisien determinasi yang di dapatkan sebesar 0,105 atau 10,5\%, sehingga dapat ditarik kesimpulan variabel gaya komunikasi guru memiliki pengaruh yang signifikan sebesar $10,5 \%$ terhadap motivasi belajar siswa pada pembelajaran daring masa pandemi COVID-19. Sedangkan 89,5\% sisanya adalah faktor-faktor yang lebih dekat dengan siswa, kemungkinan adalah faktor orang tua, lingkungan belajar, dan kegiatan-kegiatan siswa yang dilakukan di rumah di masa pandemi COVID-19 ini.

Selanjutnya berdasarkan Gambar 7 (Data Hasil Koefisien Regresi Sederhana) didapatkan model regresi sederhana yaitu $Y=42,341+1,015 X$ yang diartikan, nilai konstanta yang didapatkan adalah 42,341, menunjukkan nilai motivasi belajar siswa sebesar 1,015. Dengan koefisiensi regresi sederhana sebesar 1,015 ini dapat dinyatakan setiap pertambahan 1\% gaya komunikasi guru maka nilai motivasi belajar siswa akan bertambah juga sebesar 1,015.

Dengan kenaikan tersebut berdasar Gambar 7 (Data Hasil Koefisien Regresi Sederhana) dapat dikatakan arah dari pengaruh gaya komunikasi guru terhadap motivasi belajar pada pembelajaran dari masa pandemi COVID-19 ini adalah positif.

Uji hipotesis yang dilakukan pada Gambar 8 (Data Hasil Uji Hipotesis 1) juga memaparkan nilai signifikansi sebesar 0,006 yang lebih kecil dari standar batas signifikansi yaitu 0,05, sehingga dapat dikatakan hipotesis nol pertama $\left(\mathrm{HO}_{1}\right)$ ditolak dan hipotesis kerja pertama $\left(\mathrm{Ha}_{1}\right)$ diterima. Dan dari hasil tersebut dapat ditarik kesimpulan terdapat pengaruh yang signifikan antara gaya komunikasi guru terhadap motivasi belajar siswa pada pembelajaran daring masa pandemi COVID-19.

Kemudian berdasar Gambar 9 (Data Hasil Uji Hipotesis 2), tingkat pengaruh atau hubungan yang diperoleh berdasarkan olah data adalah sebesar 0,325 , nilai tersebut menunjukkan tingkat pengaruh yang rendah antara gaya komunikasi guru terhadap motivasi belajar pada pembelajaran daring masa pandemi COVID-19 ini, sehingga dapat disimpulkan hipotesis nol kedua $\left(\mathrm{HO}_{2}\right)$ diterima dan hipotesis kerja kedua $\left(\mathrm{Ha}_{2}\right)$ ditolak. 


\section{KESIMPULAN}

Kesimpulan penelitian ini adalah gaya komunikasi guru selama melakukan pembelajaran daring memiliki pengaruh yang signifikan terhadap pertumbuhan motivasi belajar siswa di MTs Negeri 4 Bantul. Hasil tersebut diperoleh berdasarkan data hasil uji regresi linier sederhana yang diolah melalui IBM Statistic SPSS versi 25. Dapat dibuktikan terdapat pengaruh signifikan dengan tingkat hubungan sebesar 0,325 yang tergolong rendah antara gaya komunikasi guru sebagai variabel $X$ terhadap motivasi belajar siswa sebagai variabel $Y$.

Berdasarkan nilai signifikansi juga dapat disimpulkan bahwa $\mathrm{HO}_{1}$ (hipotesis nol pertama) di tolak dan $\mathrm{Ha}_{1}$ (hipotesis kerja pertama) diterima. Sedangkan $\mathrm{HO}_{2}$ (hipotesis nol kedua) di terima dan $\mathrm{Ha}_{2}$ (hipotesis kerja kedua) ditolak.

Berdasarkan indikator variabel gaya komunikasi guru yaitu, passive style, assertive style, dan aggressive style, berpengaruh terhadap motivasi belajar siswa atas lima indikator yaitu, adanya hasrat dan keinginan untuk berhasil dalam belajar, adanya keinginan, semangat dan kebutuhan dalam belajar, memiliki harapan dan cita-cita masa depan, adanya pemberian penghargaan dalam proses belajar, adanya lingkungan yang kondusif untuk belajar dengan baik. Diperoleh hasil analisis data penelitian sebesar 10,5\%, dan 89,5\% sisanya merupakan faktor lain yang tidak diteliti dalam penelitian ini.

Dengan demikian, dapat disimpulkan walaupun hanya 10,5\% pengaruh gaya komunikasi guru terhadap motivasi belajar siswa pada pembelajaran daring masa pandemi COVID-19, tetapi pengaruhnya tetap signifikan, sehingga point ini tidak dapat diabaikan dan dapat ditingkatkan untuk menumbuhkan motivasi belajar siswa selama pandemi COVID-19.

DAFTAR PUSTAKA

Anshori, M., \& Iswati, S. (2017). Metodologi Penelitian Kuantitatif. Surabaya: Universitas Airlangga Press.

Arissandi, D., Setiawan, christina T., \& Wiludjeng, R. (2019). 23 123. Jurnal Borneo Cendekia, 3(2), 40-46.

Bantul, Mt. N. 4. (n.d.). Profil MTs N 4 Bantul. Retrieved 31 January 2021, from http://mtsn4bantul.sch.id/

Ciputra. (2016). Elaborasi dalam Berbagai Bidang. Retrieved from http://ciputrauceo.net/blog/2016/3/1/elaborasi-dalam-berbagai-bidang

DPH. (2019). Sistem Pembelajaran Daring (SPADA). Retrieved 4 November 2020, from https://www.unida.ac.id/pembelajaran/artikel/sistem-pembelajaran-daring-spada.html

Duli, N. (2019). Metodologi Penelitian Kuantitatif : Beberapa Konsep Dasar Untuk Penulisan Skripsi dan Analisis Data Dengan SPSS. Yogyakarta: Deepublish Grub CV Budi Utama.

Fitriyani, Y., Fauzi, I., \& Sari, M. Z. (2020). Motivasi Belajar Mahasiswa Pada Pembelajaran Daring Selama Pandemik COVID-19. Profesi Pendidikan Dasar, 7(1), 121-132. doi:10.23917/ppd.v7i1.10973

Ghozali, I. (2009). Aplikasi Analisis Multivariate dengan Program SPSS. Semarang: UNDIP.

Griffin, E. (2012). A First Look At Coomunication Theory Eighth Edition.

Harnani, S. (2020). Efektivitas Pembelajaran Daring Di Masa Pandemi COVID-19. BDK Jakarta Kemenag RI. Retrieved from https://bdkjakarta.kemenag.go.id/berita/efektivitaspembelajaran-daring-di-masa-pandemi-COVID-19

Hidayat, D., \& Noeraida. (2020). Pengalaman Komunikasi Siswa Melakukan Kelas Online Selama Pandemi Covid - 19. JIKE Jurnal IImu Komunikasi Efek, 3(1), 172-182. doi:10.32534/jike.v3i2.1017 
Liliweri, A. (2015). Komunikasi Antar Personal. (Satucahayapro, Ed.) (1st ed.). Jakarta: Kencana Prenana Media Group.

Littlejohn, S. W., \& Foss, K. A. (2011). Theories Of Human Tenth Edition.

Muhibbin Syah. (2008). Psikologi Pendidikan dengan Pendekatan Baru. Bandung: Remaja Rosda Karya.

Mulyana, D. (2010). Pengantar Ilmu Komunikasi. Bandung: PT Remaja Rosdakarya.

Mustofa, M. I., Chodzirin, M., Sayekti, L., \& Fauzan, R. (2019). Formulasi Model Perkuliahan Daring Sebagai Upaya Menekan Disparitas Kualitas Perguruan Tinggi. Walisongo Journal of Information Technology, 1(2), 151. doi:10.21580/wjit.2019.1.2.4067

Nasution, N. H. (2020). Pentingnya Motivasi Belajar Siswa Selama Pandemi COVID-19. Retrieved 3 November 2020, from https://www.kompasiana.com/nurhabibahnasution/5f45ebda78b6da4580042452/pentingny a-motivasi-belajar-siswa-selama-pandemi-COVID-19?page=all

Pertiwi, S. E. (2011). Gaya Komunikasi Pustakawan Terhadap Pengguna Jasa Layanan Perpustakaan. Media Pustakawan, 18(3), 50-55.

Prasetyo, B., \& Jannah, L. M. (2013). Metode Penelitian Kuantitatif Teori dan Aplikasi (8th ed.). Jakarta: PT Raja Grafindo Persada.

Purwa Atmaja Prawira. (2017). Psikologi Pendidikan Dalam Perspektif Baru. (Aziz Safa, Ed.) (II). Yogyakarta: Ar-Ruzz Media.

Rahmawati, R. (2016). Faktor-Faktor Yang Mempengaruhi Motivasi Belajar Siswa Kelas X SMA N 1 Piyungan Pada Mata Pelajaran Ekonomi Tahun Ajaran 2015/2016. Jurnal Pendidikan Dan Ekonomi, 5(4), 326-336.

Rohmah, N. (2015). Psikologi Pendidikan. (Sutomo, Ed.) (1st ed.). Yogyakarta: Kalimedia.

Santosa, P. B., \& Hamdani, M. (2007). Statistika Deskriptif dalam Bidang Ekonomi dan Niaga. Jakarta: Erlangga.

Sucia, V. (2017). Pengaruh Gaya Komunikasi Guru Terhadap Motivasi Belajar Siswa. Komuniti: Jurnal Komunikasi Dan Teknologi Informasi, 8(5), 112. doi:10.23917/komuniti.v8i5.2942

Suciati, P., Maulidiyanti, M., Triawinata, F. M., Rizkiyanti, N., Komunikasi, P., Vokasi, P. P., \& Indonesia, U. (2018). Pengaruh Gaya Komunikasi Dosen dalam Proses Pembelajaran Terhadap Motivasi Belajar Mahasiswa HUMAS Program Pendidikan Vokasi Jurnal Sosial Humaniora Terapan. Jurnal Sosial Humaniora Terapan, 1(1), 15-20.

Sugiyono. (2013). Metode Penelitian Kuantitatif Kualitatif dan R \& D. Bandung: Alfabeta.

Taniredja, T., \& Mustafidah, H. (2012). Penelitian Kuantitatif. Bandung: Alfabeta.

Tarbiyatuna, J. (2019). Gaya Komunikasi Pendidik Dan Dampaknya Terhadap Motivasi Belajar Peserta Didik di SMP Al-Firdaus Mertoyudan dan MTs Mamba ' ul Hisan Kabupaten Magelang, 10(1), 68-80.

Tim Detikcom. (2020). Respons COVID-19, Jokowi: Pelajar dan Mahasiswa Belajar dari Rumah. New.Detik.Com. Retrieved from https://news.detik.com/berita/d-4939888/respons-COVID19-jokowi-pelajar-dan-mahasiswa-belajar-dari-rumah. 